\title{
Erratum to: Determination of Selenium in Drinking Water by Electrothermal Atomic Absorption Spectrometry after Photochemical Generation, Distillation, and Preconcentration of Its Gaseous Compounds in a Graphite Furnace
}

\author{
M. Yu. Burylin ${ }^{a, *}$, K. A. Romanovskii ${ }^{a}$, and E. A. Kaigorodova ${ }^{b}$ \\ ${ }^{a}$ Faculty of Chemistry and High Technologies, Kuban State University, Krasnodar, 350040 Russia \\ ${ }^{b}$ Faculty of Agrochemistry and Plant Protection, Kuban State Agrarian University Named after I.T. Trubilin, \\ Krasnodar, 350044 Russia \\ *e-mail: burylin@chem.kubsu.ru \\ Submitted January 22, 2021; accepted for publication January 22, 2021
}

DOI: $10.1134 / \mathrm{S} 1061934821330017$

The affiliation under indication $b$ of author Kaigorodova should read as follows:

Faculty of Agrochemistry and Plant Protection, Kuban State Agrarian University Named after I.T. Trubilin

The original article can be found online at

https://doi.org/10.1134/S1061934820110040 